\title{
The Human Rights Movement Against Apartheid South Africa: The Impact of Boycotts, Divestment, and Sanctions
}

\section{Colin Wintle}

During the apartheid era of South Africa, the nation came under siege from grassroots and international social organizations for its oppressive policies of discrimination. South Africa was engaging in blatant human rights violations; its racist policies restricted the freedoms of nonwhites, and granted the white minority full authority and sovereignty. Clearly this would not go unnoticed. The development of an anti-apartheid movement brought with it a campaign of boycotts, divestment, and sanctions, which were used to attack the political, economic, and social structures of South African society and the apartheid regime of South Africa collapsed as a direct result of these pressures. Such methods of activism relied heavily on the large audience against apartheid to gain support and to have a real effect on the South African government. Without these anti-apartheid grassroots and international organizations, the impact would have been nowhere near as large, and the result may have only been a reformation of policies without true equality.

\section{Was the Anti-Apartheid Movement a Human Rights Movement?}

There is no doubt that the anti-apartheid movement was a major contributor in the fall of South African apartheid, but does this make it a human rights movement? The Oxford Dictionary defines a human rights movement quite simply as "a broad movement campaigning against the violation of human rights." ${ }^{1}$ To apply this to the anti-apartheid movement: Spanning across many nations, the anti-apartheid movement was a broad movement that fought for the

\footnotetext{
1 "Human Rights Movement," Oxford Dictionaries, accessed December 6, 2015, http://www.oxforddictionaries.com/definition/english/human-rights-movement.
} 
denied freedom and equality, as defined under the Universal Declaration of Human Rights, of non-white South Africans.

Apartheid was an incredibly discriminatory policy that denied individuals their most basic rights because of their race. It initially claimed to be built on a policy of "separate but equal" but in reality enforced a policy of "worst and minimal."2 The conditions for non-whites were terrible, and inequality was evident in a number of different aspects of society. Apartheid culture restricted access to education and opportunities to ensure a large low-paid labour force for white industry. It placed $86.3 \%$ of the country's territory in the hands of the white minority and reserved merely $13.7 \%$ for six times as many non-whites. ${ }^{3}$ It served to be "amongst the most highly institutionalized and legalized system of segregation known to modern man."4

Boycotts, divestment, and sanctions acted as the tools necessary for the anti-apartheid organizations to successfully dismantle the regime. These policies forced the South African government into granting equal human rights for all people within its territory. This campaign also did not adopt any specific political formula or enforce any political ideology; instead it focused on international law and human rights. ${ }^{5}$ In this sense, it maintained its objective of creating equality and fighting for the acknowledgement of universal human rights. Thus, apartheid was clearly a violation of human rights, making the anti-apartheid movement a human rights movement.

\section{The Development of the Anti-Apartheid Movement}

\footnotetext{
2 "International Boycott of Apartheid Sport," African National Congress, May 25, 1971, http://www.anc.org.za/show.php?id=6871\&t=Boycotts.

${ }^{3}$ Mbulelo Mzamane, "The Cultural Boycott of South Africa (I)," in Sanctioning Apartheid, ed. Robert E. Edgar (Trenton, NJ: Africa World Press, Inc., 1990), 384.

${ }^{4}$ Derrick K. Hudson-Allison, "The Role of Non-Violent Resistance in South Africa: Black Labour Movements and the Prophetic Church in the Spiral of the Apartheid State, 1980-1989," Journal of Public and International Affairs 11 (Spring 2000): 186.

${ }^{5}$ Paul Di Stefano and Mostafa Henaway, "Boycotting Apartheid From South Africa to Palestine," Peace Review: A Journal of Social Justice 26 (2014): 25.
} 
In its early phases, the anti-apartheid movement was very disorganized and disconnected. It was more of an assortment of social and human rights organizations than an actual human rights movement. As it developed, the anti-apartheid movement overcame its internal divisions, became more professional in its organization and universal in its policies, and transformed into more of a rights-based movement. It encountered many challenges throughout the years, especially with the neoliberal policy of 'constructive engagement' as put forward by Ronald Reagan and Margaret Thatcher, but persevered. In becoming more developed and organized, the movement was able to more effectively lobby government and corporations, as well as gain mass support for the effective role of boycotts, divestment, and sanctions.

One of the first major internal struggles that the movement faced was the issue of violent and non-violent resistance. The African National Congress (ANC) was initially an advocate for violent resistance to overthrow apartheid from within South Africa. The ANC had been working at training thousands of South African exiles "to carry out sabotage missions and incite unrest aimed at rendering the townships ungovernable." ${ }^{\prime 6}$ This went against the concept of non-violent resistance that many other organizations were working towards. Non-violent resistance used "boycotts, sit-ins, occupations, demonstrations, refusal to pay taxes, creation of alternative and parallel institutions, and other forms of civil disobedience" to try and peacefully remove apartheid. ${ }^{7}$ The major issue was that the violent resistance used by the ANC and other groups undermined non-violent resistance as "the government linked the two organizations and used this propaganda to justify their increased repression." ${ }^{8}$ It would eventually be non-violent resistance

\footnotetext{
${ }^{6}$ Kathleen C. Schwartzman and Kristie A. Taylor, "What Caused the Collapse of Apartheid?," Journal of Political and Military Sociology 27, no. 1 (Summer 1999): 119.

${ }^{7}$ Hudson-Allison, "The Role of Non-Violent Resistance in South Africa," 192.

${ }^{8}$ Ibid.
} 
through boycotts, divestment, and sanctions that proved to be the most effective in dismantling apartheid, however.

Another challenge that the movement had to overcome was its initial disorganization. The heavily decentralized and segmented nature of the developing movement resulted in the absence of a leader. For this reason the movement developed slowly. ${ }^{9}$ Even Canadian efforts experienced this issue of broad disorganization as they never really assumed the same form of centralization that the UK and the US experienced. ${ }^{10}$ As apartheid was making successes and achieving victories, the movement that had come together was already beginning to wither away. It was almost forgotten before apartheid had even formally been removed. ${ }^{11}$ Organizations elsewhere did not all suffer the same fate but instead developed over time and became more effective at using their tactics.

Professionalization started to occur more as the movement became organized in the 1960s. One of the first individuals to give the movement authority in government was Michigan representative Charles C. Diggs. In 1969, Diggs became Chair of the House Subcommittee on Africa. ${ }^{12}$ At the same time, President Richard Nixon was increasing trade with South Africa and trying to build a better relationship with the white government there as well as in Angola, Mozambique, and Rhodesia. For instance, Nixon was selling aircrafts and other goods that had been "prohibited under the terms of the United Nations arms embargo."13 Diggs led hearings in the House regarding "UN sanctions against Rhodesia, U.S. business involvement in South

\footnotetext{
${ }^{9}$ Donald R. Culverson, "The Politics of the Anti-Apartheid Movement in the United States, 1969-1986," Political Science Quarterly 111, no. 1 (Spring 1996): 136.

${ }^{10}$ Chris Webb, "Hidden Histories \& Political Legacies of the Canadian Anti-Apartheid Movement," Canadian Dimension 48, no. 2 (April 2014): 20.

${ }^{11}$ John S. Saul, "Two Fronts of Anti-Apartheid Struggle: South Africa and Canada," Transformation: Critical Perspectives on Southern Africa 74 (2010): 142.

${ }^{12}$ Culverson, "The Politics of the Anti-Apartheid Movement in the United States," 134.

${ }^{13}$ Ibid., 133.
} 
Africa, and political repression in both states. ${ }^{114}$ His position in the House provided a platform for scholars and activists as well as representatives of anti-apartheid organizations to be heard. It created a political discourse and debated the Nixon administration on a number of different issues, becoming "a vehicle for conveying the Africanist concerns of black Americans." ${ }^{15}$ Diggs essentially acted as an authority in the American House of Representatives, helping to spread the word of anti-apartheid groups and bring the movement together in America.

A significant organization that exerted professionalism and formal organization in the movement was TransAfrica. This organization came together in 1977 as interest in foreign affairs increased among black Americans. It quickly established itself as "one of the most vocal and consistent critics of apartheid." ${ }^{\prime 16}$ Its leadership was made up of professional activists with years of experience through earlier attempts at creating a permanent Afro-American foreign policy organization. ${ }^{17}$ The Congressional Black Caucus was also a major supporter of the antiapartheid movement, and a supporter of TransAfrica. By 1985, a number of its members had been promoted to leadership positions on powerful committees, thereby increasing congressional support for the movement across a number of different committees. ${ }^{18}$ Through its newly established connections in governing bodies, the anti-apartheid movement was becoming more present in the world of international politics, and had a larger stage to launch its campaign from.

The transition to universal human rights and the shift to rights-based activism can be seen through the example of the British labour movement and solidarity. The British Anti-Apartheid Movement (AAM) worked with trade unionists to convince them of the need for disengagement. Using few resources, it was able to hold conferences for grassroots trade unionists and "engaged

\footnotetext{
${ }^{14}$ Culverson, "The Politics of the Anti-Apartheid Movement in the United States," 133.

${ }^{15}$ Ibid., 134.

16 Ibid., 141.

${ }^{17}$ Ibid.

${ }^{18}$ Ibid., 144.
} 
with the growing shop stewards movement and made contacts in companies that supplied military and other sensitive material to South Africa." ${ }^{19}$ It made its appeal for trade union support on the grounds that both British and South African workers shared an interest in demanding higher wages. They were to be united in a fight against multinational companies with British workers demanding more capital investment in Britain. ${ }^{20}$ This appeal essentially worked on the principle of reframing the argument; no longer was this to be a movement for selective human rights, but universal human rights. The AAM extended the concept of human rights beyond South Africa and framed them to be for the benefit of the British working-class as well.

Clearly, over time, the movement was becoming more concise and more powerful in its activism against the apartheid regime of South Africa. With this cohesion, its impact soon began to peak. After 1979, "the emphasis of the opposition movement shifted from ideological realignment and unity to action." ${ }^{21}$ Boycotts, divestment, and sanctions were in full force and receiving widespread support. Organizations were working together, and the anti-apartheid movement was truly established as a human rights movement. The transition from uncoordinated and more individual activism to organized and collective action was proving to be crucial in the fight against apartheid. ${ }^{22}$ States and local governments, as well as colleges and universities, and corporations were reassessing their ties to apartheid as a result of the growing grassroots activism. ${ }^{23}$ Thus, professionalization and formal organization led to a more focused movement against the apartheid regime in South Africa. This newfound support of the movement also contributed to an increased support from other institutions that served to further strengthen it.

\footnotetext{
${ }^{19}$ Christabel Gurney, “The 1970s: The Anti-Apartheid Movement's Difficult Decade," Journal of Southern African Studies 35, no. 2 (June 2009): 476.

${ }^{20}$ Ibid.

${ }^{21}$ Schwartzman and Taylor, "What Caused the Collapse of Apartheid?," 119.

22 Ibid., 118.

${ }^{23}$ Culverson, "The Politics of the Anti-Apartheid Movement in the United States," 127.
} 
The anti-apartheid movement was, of course, not without its challenges. This was especially the case during the presidency of Ronald Reagan and the leadership of Margaret Thatcher. While the movement was gaining a large amount of support through the 1970s, it was immediately challenged by the neoliberal concept of 'constructive engagement.' This method of diplomacy would allow Thatcher and Reagan to attempt to improve relations with South Africa and reject the sanctions that were being used against it. For Thatcher it was "embracing the ideological mantra 'free economy and the strong state." 24 For Reagan it was also very much the same. ${ }^{25}$ Through the guise of economic policies that would apparently help South Africa, Thatcher and Reagan were able to engage in an act of self-interest while supposedly supporting human rights. $^{26}$

Although constructive engagement was more of "a convenient cover for business and governments," it was also quite willingly embraced by groups "genuinely opposed to apartheid [that] feared the implications of rapid disengagement." 27 The origins of these fears can undoubtedly be found in the rhetoric of the Cold War. Around the time of 'constructive engagement,' the governments of Angola and Mozambique had fallen to Marxist revolutionaries while Zimbabwe was undergoing a threat of revolution. ${ }^{28}$ There was a fear that heavy sanctions would push South Africa into a left-wing revolution, and that the best method of preventing a communist political struggle would be to increase diplomatic and economic relations. This caused a genuine dilemma for the movement. While 'constructive engagement' manipulated some forms of anti-apartheid activism, it was still advocated by a number of individuals and

\footnotetext{
24 Mathew Llewellyn, "Circumventing Apartheid: Racial Politics and the Issue of South Africa’s Olympic Participation at the 1984 Los Angeles Games," The International Journal of the History of Sport 32, no. 1 (2015): 60 .

25 Ibid.

${ }^{26}$ William H. Shaw, “Boycotting South Africa,” Journal of Applied Philosophy 3, no. 1 (1986): 61.

${ }^{27}$ Gurney, “The 1970s: The Anti-Apartheid Movement's Difficult Decade," 472.

${ }^{28}$ Ibid., 484.
} 
organizations devoted to ending apartheid. ${ }^{29} \mathrm{~A}$ new divide erupted and briefly slowed the antiapartheid movement. This was however, a short-lived defeat.

There was eventually a distancing from Reagan and 'constructive engagement' in America. In December of 1984, twenty-five conservative Republican House members went against the Reagan administration as they wrote a letter to the South African ambassador that threatened his government with sanctions until apartheid was dismantled. ${ }^{30}$ This proved an end of support for 'constructive engagement.' In 1986, Congress also overruled Reagan's veto of the Anti-Apartheid Act, which put forward the:

"prohibition of the importation for South African coal, steel, textiles, uranium, agricultural products, and products produced by South African parastatals; application of these sanctions to South African-controlled Namibia; prohibition of the landing of South African airlines in the U.S. and of the American airlines in South Africa; prevention of the U.S. corporations from deducting South African taxes from their income; prohibition of new corporate investments in governmental agencies." 31

Finally, the anti-apartheid movement had overcome the challenge of 'constructive engagement' and the implementation of sanctions had returned. Although Reagan had attempted to keep the anti-apartheid movement out of Congress, he was unsuccessful and its influence came back to the forefront of pressuring South Africa into dismantling apartheid.

After this achievement, the anti-apartheid movement went through a progressive series of developments in order to increase support and influence in the dismantling of apartheid in South Africa. The movement began much disorganized but came together under professionals. Its policies became more universal, extending the movement to reach a larger audience and increasing its support. Growth of support was exponential, providing a larger audience in favour of boycotts, divestment, and sanctions and in turn increasing their effectiveness.

\footnotetext{
${ }^{29}$ Håkan Thörn, "The Globalization of the Anti-Apartheid Movement," in Anti-Apartheid and the Emergence of a Global Civil Society (New York: Palgrave Macmillan, 2006), 66.

${ }^{30}$ Culverson, "The Politics of the Anti-Apartheid Movement in the United States," 144-145.

${ }^{31}$ Ibid., 146.
} 


\section{Boycotts, Divestment, and Sanctions}

Boycotts, divestment, and sanctions were some of the major tools used by the antiapartheid movement against apartheid South Africa. The initiatives began fairly early in the movement. Starting in the 1950s as apartheid was coming to fruition, they were carried through to the early 1990 s as apartheid was ending. ${ }^{32}$ They clearly operated as rights-based initiatives that forced compliance with international law in order to ensure the respect of basic human rights for the non-white South African population. ${ }^{33}$ The tools grew in size and in strength as the years went on, highlighting the inequality that non-white South Africans were suffering as well as the human rights abuses that existed under apartheid.

Boycotts were widespread and easy for individuals to get involved in. ${ }^{34}$ A very influential form of boycott was the sports boycott. Sports boycotts kept South Africa out of the Olympic games and tarnished their international rugby and cricket teams, causing upsets within the state and a great deal of embarrassment. They were used as a means of "exposing injustices while simultaneously exerting economic pressure as leverage in the struggle for freedom, equality, and an end to colonialism." 35 In extending past the government and into institutions and events, boycotts were an effective method of influencing the government and its policies.

Sports boycotts were indeed some of the most effective boycotts implemented in the antiapartheid movement. In apartheid South Africa, sports were generally reserved for whites, especially at the international level. This was a policy that also would be applied to visiting international teams. ${ }^{36}$ In applying apartheid policies to international teams that were visiting, South Africa had essentially imposed its racist policies across international borders. By

\footnotetext{
${ }^{32}$ Di Stefano and Henaway, "Boycotting Apartheid From South Africa to Palestine," 19.

${ }^{33}$ Ibid., 22.

34 Thörn, "The Globalization of the Anti-Apartheid Movement," 61.

${ }^{35}$ Di Stefano and Henaway, "Boycotting Apartheid From South Africa to Palestine," 19.

36 "International Boycott of Apartheid Sport."
} 
extension, in accepting invitations from, or in inviting all-white South African teams to visit would be either accepting or welcoming the policies of apartheid. This eventually became a very controversial issue that provided an argument for the use of sports boycotts. The largest and most damaging sports boycott campaigns were the Stop-the-Seventy-Tour, and the Olympic boycott.

The Stop-the-Seventy-Tour is arguably one of the most successful mass-action antiapartheid protests in British history. Its efforts led to the cancellation of the 1970 England-South Africa Springbok cricket series. ${ }^{37}$ The origins of this particular campaign come from the nationwide protests and demonstrations in Britain and Ireland when the all-white South African rugby team conducted a tour in 1969. At each event protestors would clash with police in their attempts to boycott the games. An estimated 50,000 people took part in the demonstrations. ${ }^{38}$ There was also an ultimatum being put forward as a majority of countries within the Commonwealth were threatening to boycott the Commonwealth Games if the Springbok cricket tour went on. This forced the British government to cancel the tour for fear of further embarrassment. ${ }^{39}$ The cancellation of the tour proved that apartheid policies in international sporting events would no longer be tolerated.

The second major sports boycott campaign was the Olympic campaign. Within South Africa, the South African Non-Racial Olympic Committee (SAN-ROC) was formed in 1962. The committee's main objective was the removal of apartheid policies in sport and the introduction of non-white South African athletes in the Olympics. ${ }^{40}$ At around the same time, the AAM was also working towards the elimination of apartheid sport in the Olympics. ${ }^{41}$ Similar to the statements made earlier, the participation of an all-white South African team representing

\footnotetext{
${ }^{37}$ Llewellyn, "Circumventing Apartheid," 473.

38 "International Boycott of Apartheid Sport."

${ }^{39}$ Ibid.

${ }^{40}$ Ibid.

${ }^{41}$ Ibid.
} 
apartheid principles on an international stage could be extended to the welcoming of human rights abuses. It took a few years to develop, but as a result of boycott campaigns South Africa was officially banned from the Olympics on May 15, 1970. The impact on apartheid was not as effective as it was hoped to be, however. In South Africa, the dominant sports are rugby and cricket and neither of which would have been present in the Olympics. ${ }^{42}$ As such, unlike the cancellation of the Springbok Cricket Tour, South Africa's exclusion from the Olympics had a smaller effect.

Regardless, by 1984 Pretoria had implemented desegregation of its sports teams in an effort to gain readmission to the Olympics. This brought with it a number of pickets of the Los Angeles Olympic Organizing Committee (LAOOC), the South African Embassy, and the International Olympic Committee (IOC) ${ }^{43}$ Although this attempt at desegregation may have only been the appearance of reforming apartheid with no real substance to it, it does show that South Africa acknowledges apartheid as internationally unacceptable. It also shows the impact that the campaign was starting to bring as South Africa's embarrassment was building.

Boycotts in these instances ultimately show accessibility for individuals to take part in this method of protest, as well as their potential for lasting effects. Embarrassment on the international level contributed a social impact that alone was not substantial, but in combination with divestment and sanctions had much more potential to deter apartheid policies.

Divestment was also a very useful tool during the anti-apartheid movement and contributed a large economic and political impact. It has been criticized for its tremendous effects on economies; this of course is to be expected for a powerful form of protest. ${ }^{44}$ It targeted

\footnotetext{
${ }^{42}$ Llewellyn, "Circumventing Apartheid," 58.

${ }^{43}$ Ibid., 53-54.

${ }^{44}$ Rodney J. Douglas, R.J. Rayner, and J.C. Masters, "Boycotting South Africa," Nature 330, no. 5 (November 1987): 10.
} 
corporations seen as complicit in the violation of human rights. Essentially the opposite of investing, divestment is the reallocating of investments, in this case their withdrawal from corporations operating within or profiting from apartheid South Africa. This tactic was most effective in inspiring the end to apartheid when large corporations would withdraw or refuse to invest. ${ }^{45}$ Its implementation had a direct effect on the economy of South Africa and reduced the amount of foreign investment. It was also a representative from of political pressure, directly affecting the economy and simultaneously bypassing the nation-state. ${ }^{46}$ Quoting from Håkan Thörn, Meg Voorhes has put forward that there are several functions of divestment: "it "directly influenced corporate policy, reinforced grassroots anti-apartheid mobilization, and contributed to the dramatic public shift in favour of sanctions against South Africa." ${ }^{47}$ The ability of divestment to infiltrate the South African economy and directly influence the apartheid regime made it an extremely effective tool in the anti-apartheid movement.

Sanctions were also implemented through the efforts of the anti-apartheid movement. They are said to be the hardest initiatives to implement but those with the highest degree of efficiency. ${ }^{48}$ Sanctions were created through the lobbying of governments and larger international corporations in an attempt to upset the status quo and pressure South Africa into ending apartheid. ${ }^{49}$ They illustrate the power of a nation state being used as an instrument in pressuring South Africa. ${ }^{50}$ An example of this power would be the AAM's ability to lobby the Labour government. From 1970-1974, sanctions were very difficult to lobby for in the House as they were shut down by the Conservative government that was in power at the time. It was after

\footnotetext{
${ }^{45}$ Di Stefano and Henaway, "Boycotting Apartheid From South Africa to Palestine," 24.

${ }^{46}$ Thörn, "The Globalization of the Anti-Apartheid Movement," 61.

${ }^{47}$ Ibid., 62.

${ }^{48}$ Di Stefano and Henaway, "Boycotting Apartheid From South Africa to Palestine," 24.

${ }^{49}$ Ibid., 25.

${ }^{50}$ Thörn, "The Globalization of the Anti-Apartheid Movement," 60-61.
} 
1974 and with the victory of the Labour Party that sanctions became more successful, resulting in the compliance with the UN arms embargo. ${ }^{51}$ Sanctions were almost always vetoed by Western powers of the Security Council when they were proposed to the UN. This changed in the mid-1980s, where between 1985 and 1987, "Britain, France, Spain, Panama, Portugal, and the United States introduced economic sanctions." 52 Sanctions thus became a much larger part of the anti-apartheid movement after a view of its first successes in divestment and through boycotts. They were undoubtedly a reflection of the growing support for the anti-apartheid movement.

\section{The Impact of Boycotts, Divestment, and Sanctions}

The campaign of boycotts, divestment, and sanctions had a very large impact on the apartheid regime of South Africa. For example, the Nationalist parties in South Africa suffered greatly as a result of discontent among the white population of the country. There were many connections to apartheid, international sanctions, and the economic well-being of the population. The result was a drop in support for the Nationalist parties from $68 \%$ in 1984 to $56 \%$ in $1989 .{ }^{53}$ This time frame is significant as it was a considerable turning point in the anti-apartheid movement. As we have seen, between 1984 and 1989 the policies of 'constructive engagement' fell apart, providing a return to more isolating forms of protest against South Africa. The implementations of sanctions from powerful nations increased during this time. America implemented the Anti-Apartheid Act; and South Africa was again denied admittance into the Olympics. This brings out the true strength of the boycotts, divestment, and sanctions campaigns: their ability to suggest horizontal processes "whereby grassroots organizations can choose their

\footnotetext{
${ }^{51}$ Gurney, "The 1970s: The Anti-Apartheid Movement's Difficult Decade," 485-486.

52 Thörn, "The Globalization of the Anti-Apartheid Movement," 64-65.

${ }^{53}$ Schwartzman and Taylor, "What Caused the Collapse of Apartheid?," 111-112.
} 
target, tactics, and strategy according to the specificities of their individual contexts and, therefore, contribute in myriad ways." ${ }^{, 54}$ These policies, in combination with each other and the strength of the anti-apartheid movement, ultimately led to the dismantling of apartheid in South Africa.

The impact of divestment was incredibly substantial. It is said that divestment was the most powerful means of deterring apartheid policies in South Africa. This can be attributed greatly to its ability to directly affect the economy and indirectly affect government policy. The impact of divestment is quite easy to see. In 1970, direct investment constituted $68 \%$ of total foreign investment, but after fourteen years of divestment promotion through the anti-apartheid movement, direct investment had dropped to $39 \%$ in $1984 .{ }^{55}$ Likewise, the amount of US investment dropped from $\$ 2.8$ billion in 1983 to $\$ 1.3$ billion in 1985 , with 350 US companies having fully pulled out of South Africa by $1987 .{ }^{56}$ In just over a decade divestment was able to cripple foreign investment into South Africa and have an enormous effect on its economy.

Sanctions were seen as the most widespread initiative however, and their impact was much more predictable. They had a large impact on foreign capital inflows and resulted in a small number of exports for South Africa. ${ }^{57}$ The most lasting impact that sanctions would have however, was in the way that they forced South Africa to become more self-sufficient and dependent on its labour force, opening higher positions for non-whites - though still not granting them their universal human rights. ${ }^{58}$ Sanctions, much like divestment, affected the economy of South Africa and contributed in upsetting the status quo in such a way that South Africa was forced to abandon its policy of apartheid.

\footnotetext{
${ }^{54}$ Di Stefano and Henaway, "Boycotting Apartheid From South Africa to Palestine," 25.

${ }^{55}$ Schwartzman and Taylor, "What Caused the Collapse of Apartheid?," 116.

${ }^{56}$ Culverson, "The Politics of the Anti-Apartheid Movement in the United States," 146.

${ }^{57}$ Schwartzman and Taylor, "What Caused the Collapse of Apartheid?," 126.

${ }^{58}$ Gurney, “The 1970s: The Anti-Apartheid Movement's Difficult Decade," 486.
} 
Boycotts may have been a form of activism that was easier to implement on a variety of different scales, but it provided a very extensive impact on apartheid in South Africa. The very threat of boycotts of South Africa in the 1984 Olympics pushed the leader of the IOC to go against the Olympic Charter and keep South Africa out of the Olympics - making the decision as early as $1981 .^{59}$ This showed the power the boycotts had built up, and the authority they carried. The boycotts were seen as being so effective that even the IOC would not be able to withstand their financial and diplomatic fall-out. ${ }^{60}$ South Africa would finally rejoin the Olympic community in Barcelona in 1992, "following the commencement of governmental talks to finally bring an end to apartheid." 61

Ultimately, the campaigns of boycotts, divestment, and sanctions proved to be the most effective tools accessible to the anti-apartheid movement; allowing it to accomplish its goal of ending apartheid in South Africa.

\section{Conclusion}

In conclusion, the collapse of the apartheid system of governing in South Africa was the direct result of a campaign of boycotts, divestment, and sanctions instituted through the antiapartheid movement. Without the collective action of countless organizations within the movement, this campaign would not have been as effective. The impact and the success in dismantling apartheid came from the development of the anti-apartheid movement and the growth in support it created for itself. Through boycotts, divestment, and sanctions, the antiapartheid movement was able to infiltrate South Africa socially, economically, and politically,

\footnotetext{
${ }^{59}$ Llewellyn, "Circumventing Apartheid," 62.

${ }^{60}$ Ibid., 63.

${ }^{61}$ Ibid., 67.
} 
ending the human rights abusing apartheid regime and ensuring freedom and human rights for the non-white population. 


\section{Bibliography}

Culverson, Donald R. "The Politics of the Anti-Apartheid Movement in the United States, 19691986." Political Science Quarterly 111, no. 1 (Spring 1996): 127-49.

Di Stefano, Paul, and Mostafa Henaway. "Boycotting Apartheid From South Africa to Palestine.” Peace Review: A Journal of Social Justice 26 (2014): 19-27.

Douglas, Rodney J., R.J. Rayner, and J.C. Masters. "Boycotting South Africa." Nature 330, no. 5 (November 1987): 10.

Gurney, Christabel. "The 1970s: The Anti-Apartheid Movement's Difficult Decade." Journal of Southern African Studies 35, no. 2 (June 2009): 471-87.

Hudson-Allison, Derrick K. "The Role of Non-Violent Resistance in South Africa: Black Labour Movements and the Prophetic Church in the Spiral of the Apartheid State, 1980-1989.' Journal of Public and International Affairs 11 (Spring 2000): 185-205.

"Human Rights Movement." Oxford Dictionaries. Accessed December 6, 2015. http://www.oxforddictionaries.com/definition/english/human-rights-movement.

“International Boycott of Apartheid Sport.” African National Congress, May 25, 1971. http://www.anc.org.za/show.php?id=6871\&t=Boycotts.

Llewellyn, Mathew. "Circumventing Apartheid: Racial Politics and the Issue of South Africa's Olympic Participation at the 1984 Los Angeles Games." The International Journal of the History of Sport 32, no. 1 (2015): 53-71.

Mzamane, Mbulelo. "The Cultural Boycott of South Africa (I)." In Sanctioning Apartheid, edited by Robert E. Edgar. Trenton, NJ: Africa World Press, Inc., 1990.

Saul, John S. "Two Fronts of Anti-Apartheid Struggle: South Africa and Canada." Transformation: Critical Perspectives on Southern Africa 74 (2010): 135-51.

Schwartzman, Kathleen C., and Kristie A. Taylor. "What Caused the Collapse of Apartheid?" Journal of Political and Military Sociology 27, no. 1 (Summer 1999): 109-39.

Shaw, William H. "Boycotting South Africa.” Journal of Applied Philosophy 3, no. 1 (1986): 59-72.

Thörn, Håkan. "The Globalization of the Anti-Apartheid Movement." In Anti-Apartheid and the Emergence of a Global Civil Society, 48-72. New York: Palgrave Macmillan, 2006.

Webb, Chris. "Hidden Histories \& Political Legacies of the Canadian Anti-Apartheid Movement." Canadian Dimension 48, no. 2 (April 2014): 19-22. 